"The policies and collaborations between governments and civil society that kept forests standing in many parts of Amazonia have come to an end, at least for now."

\title{
Why the Brazilian Amazon Burns
}

\author{
SUSANNA HECHT
}

$\mathrm{T}$ he Amazon was in flames in August 2019. How much forest had to burn to shroud the Western Hemisphere's largest megacity, São Paulo, in enough smoke to completely darken its skies, about 2,500 kilometres from the Amazon? The area that burned across the Brazilian Amazon in all of 2019 amounted to over 6 million hectares (about 60,000 square kilometers), and another 2 million hectares were on fire in Bolivia, according to the World Wildlife Fund. The number of fires was up almost 80 percent from the same period in 2018, based on remote-sensor data from Brazil's Institute for Spatial Studies-whose director, physicist Ricardo Galvão, was fired for reporting this fact to right-wing President Jair Bolsonaro.

Other major South American cities, from Santa Cruz, Bolivia, to the soybean entrepôt of Porto Velho in the upper Amazon River basin in northwest Brazil, were also wheezing through unbreathable air and darkness at noon. There was an explosion in hospital visits, including many newly asthmatic and choking children.

It was hard to imagine that smoke could travel so far and blanket such huge areas. But the subsequent conflagrations at the end of the year in Australia are schooling everyone in the relentless realities of fire. Smoke from those bushfires produced a plume that traveled more than 9,000 miles and now drapes Chile and southern Brazil in yet more soot-saturated air. The Australian fires, however, were triggered by natural processes intensified by climate change-including temperatures among the highest ever recorded in Australia (120 degrees Fahrenheit), strong winds, and lightning. The Amazonian fires, in contrast, were purposefully set to clear land for speculation and agricultural use, in an unprecedented outbreak of

SUSANNA HECHT is a professor of international history at the Graduate Institute, Geneva, and a professor of urban planning at the University of California, Los Angeles. planetary arson. Although Amazon forest is often burned to prevent regrowth on pasture, new deforestations of some two million hectares accounted for a third of the clearing.

The shocking images of the Amazon fires were a grim illustration of the hottest summer ever recorded, in the second-hottest year. Paris vied with Death Valley for the hottest spot on the planet for a few days (111 degrees Fahrenheit), while Fairbanks, Alaska, basked in 90-degree heat. Siberian fires blazed in the Arctic, and glaciers dissolved at unprecedented rates. The catastrophe was captured by satellites; the fires were dramatically visible from space, from drones, and from ground photos that made the heat feel palpable.

The DNA of the most complex ecosystems on the planet became mere ashes, combining with forest fire smoke to form a new kind of urban pollution and add more greenhouse gases to the atmosphere. Plants and animals were reduced to their constituent chemicals, leaving behind the charred remains of immolated environments, perhaps now gone forever. Scientists estimated that a billion animals died in the Australian infernos. Social media was awash with poignant photos of iconic koalas, wombats, and kangaroos framed against the flaming backdrops of their former forest habitats.

In Brazil, scholars and zoologists from the $\mathrm{Na}$ tional Institute for Amazonian Research (INPA), the Chico Mendes Institute for Biodiversity Conservation (ICMBio, the agency that manages Brazil's national parks), and the World Wildlife Fund were assessing the fires' impacts on one of the earth's most diverse regions. The Brazilian Amazon hosts an unknown number of species (at least 30,000) and highly varied habitats rife with endemic species-local organisms adapted to specific localities. No one could yet estimate a total death tollperhaps they lacked the heart for it-but there were indications that 265 species were threatened 
with extinction, potentially making this fire season a definitive biotic annihilation event.

Bolivian scientists estimated that the destruction of their far less analyzed Amazon forests had immolated some two million animals. Yet President Evo Morales-soon to be driven from office over his attempt to stay on for a fourth term-presided in August over the first shipment of Bolivian Amazon beef to China at an event held not far from the unique Chiquitanía forests, large swaths of which were being burned to cinders at that moment.

However many species perished in the firestorms, countless more will die from lack of food and from wounds and predation as they roam the scorched ruins of their ecosystems. We might usefully set the number of human lives lost-a few hundred-against the multiple billions of other organisms that expired, or will soon, because of the conflagrations.

More ecocide is likely on the way. In 2018, scientists Carlos Nobre and Tom Lovejoy warned of a tipping point looming close on the horizon, when Amazonia, instead of absorbing carbon, will begin to release its 100 billion tons of stored $\mathrm{CO}_{2}$, becoming a source rather than a sink of greenhouse gases, less able to regulate the regional as well as the global climate: the forest ecosystem will transform into a more arid kind of landscape, as vegetation change and atmospheric heating act on each other in a noxious feedback loop. Ecosystem modelers from Brazil and the United States warn that climate change and tree clearing are increasing the vulnerability of southern Amazonia's forests to more fires, of greater intensity and extent.

\section{BOLSONARO'S BLAME GAME}

The ghastly images of the Amazon in flames triggered a global outcry. Yet Brazil's environment minister, Ricardo Salles, views climate change as a "secondary issue." Bolsonaro is a climate change skeptic. His foreign minister, Ernesto Araujo, dismisses climate change as a figment of what he calls "cultural Marxist" propaganda. In a September speech at the Heritage Foundation, a conservative US think tank, he denied that the Amazon was burning at all.

What is the meaning or value of environmental stewardship if you believe in the end times, as do leading members of Brazil's ascendant Evangeli- cal Christian movement, not least Bolsonaro and his coterie? The slogan of his political supporters, "bibles, beef, and bullets," more or less sums up the components of his coalition: fundamentalist Christians, the agricultural industry, and the military. Brazil's agro-elites were perfectly willing to burn up more than 40,000 species of plants to make a habitat for just one-soy-and to immolate an ecosystem of more than 150,000 different kinds of animals (surely an underestimate) to make space for a single species, the cow.

Such destructive behavior could usher us out of the Anthropocene-this geological epoch dominated by human activity-into what the biologist E.O. Wilson has called the Eremocene, the age of loneliness, as we preside over mass extinctions not unlike those triggered by the asteroid impact that ended the days of the dinosaurs. But if you have a providential worldview, you might believe that the world was made for the use of man, and for his profit.

Nonetheless, Brazil's defiant leaders suddenly found themselves on the defensive. At the August 2019 G7 summit in Biarritz, France, the burning Amazon and climate change leaped onto the agenda. Given that a global climate summit in New York was to take place in September, the Vatican would host an Amazon Synod in October, and the annual United Nations climate meeting was set for December (Brazil was originally to host it, but Bolsanaro canceled shortly after taking office), the Brazilians faced the prospect of having to discuss the Amazon all fall.

Bolsonaro vaulted into action with typically rebarbative rhetoric and blame shifting. First, he refused the 22 million euros in emergency funds offered by the European Union because he felt that French President Emmanuel Macron had insulted him in a colonial manner by calling for a discussion of the Amazon fires at the G7 summit. Amazonian states at this time were scrambling for assistance to help pay for firefighters and fuel for planes that were making symbolic water drops; the scale of the fires precluded any meaningful efforts to control them.

A hasty September summit of the leaders of Amazon countries (Bolsonaro did not attend) was organized in Leticia, Colombia, to discuss deforestation, but yielded only a banal document seemingly designed to mollify the international community 
and donors. It offered platitudes about mutual help, green innovation, information sharing, and securing the inclusion and consent of indigenous people for development initiatives. In reality, no Amazon country follows the International Labor Organization's indigenous consent law (ILO Convention 169), which took force in 2016. Meanwhile, also in September, Araujo and US Secretary of State Mike Pompeo announced a \$100 million deal to "protect biodiversity" and create business opportunities in the most remote and inaccessible areas of Amazonia - for which read plundering in protected areas and indigenous reserves by mining and timber interests.

The Bolsonaro team organized its blame-shifting campaign by deploying a well-rehearsed playbook. First, Bolsonaro accused the international media of biased reporting intended to damage Brazil's global standing by misrepresenting deforestation as wanton destruction rather than as a necessary part of the process of Brazilian development. He also invoked global conspiracies, alleging that subversive international nongovernmental organizations were setting the fires and then spreading videos of them to make his government look bad.

NGOs were doing this, Bolsonaro alleged, because Germany and Norway had frozen 87 million euros in contributions to the Amazon Fund, which finances projects to reduce deforestation: more monitoring of clearing, help with titling, eco-certification, agroforestry experiments, payment for land demarcation, and related projects, many of which are directed by NGOs and social movements. This funding could be understood as a broadly defined payment for environmental services. It supports development programs that are not based on deforestation. Germany and Norway, which provide most of the Fund's money, suspended their contributions because of the lack of progress in controlling deforestation and increasing attacks on environmental institutions in Brazil.

Bolsonaro's government has threatened environmental NGOs, especially Greenpeace and the World Wildlife Fund, that they could be banned from Brazil as subversive antigovernment organizations. In his theater of the absurd, Bolsonaro blamed the actor Leonardo DiCaprio and his foundation for fomenting sedition through environmental fundraising. Even local NGOs of volunteer firefighters in Alter do Chão were accused of set- ting fires and then filming them, though the charges were dropped for lack of evidence. Government funding for Brazil's own NGOs, many of which work with indigenous and traditional peoples, had already been cut off, and those that receive international funds are now also subjected to detailed auditing, under an order issued by Salles in January 2019. Even the conservative pro-Bolsanaro TV network Globo called this move a "war against NGOs."

Bolsonaro and his allies claimed that efforts to inhibit Amazonian deforestation masked more sinister geopolitical strategies, including a European plot to limit imports of cheap Brazilian agricultural goods by backing out of the EU's free trade agreement with Mercosur, the South American economic bloc, on specious environmental grounds. In a more ominous register revived from the era of dictatorship in Brazil, they claimed that inhibiting deforestation was meant to forever condemn the nation to underdevelopment by thwarting its agroindustrial ranchers and soy farmers from taking their rightful position as Amazonian territorial masters and suppliers to overseas markets, mainly China. Another popular trope was a warning that locking up the Amazon's resources in parks and protected areas would provide a pretext for foreign invasion when other countries ran out of resources. As the controversy wore on, these issues of territoriality and sovereignty became pivotal.

"Amazonia is ours," Bolsonaro often reiterates, articulating a view popular in military circles that environmentalists use indigenous people as stooges to threaten Brazilian sovereignty and the Christian way of life by asserting claims to selfrule. (Indigenous autonomy is inscribed in the 1988 constitution.) The fear is that these native "nations" could become platforms for an invasion from within, a sort of "eco-foco," to update the revolutionary terminology of Che Guevara. "They do not have lobbyists and do not even speak Portuguese. How is it that indigenous people have ended up with so much of our land?" asked Bolsonaro at a 2015 meeting in the soy entrepôt of Campo Grande.

Bolsonaro's son Eduardo argued in the Brazilian Congress that the United States and Europe had both developed by plundering their natural resources, so who were they to tell Brazil what to do? In fact, imperialism, innovation, and industri- 
alization have had more to do with US and European development than domestic forest exploitation. Both have more forest now than they did in the early nineteenth century-more than 90 percent of it is native woodland. The Bolsonaros and their entourage, evidently uninformed about this, urged the G7 leaders to take their cash and use it to reforest their own countries.

One reason for the existence of these American and European temperate-zone forests is the historical development of regulatory and protective legal apparatuses, careful forest management, and the structural shift away from a liquidation economy like that which currently prevails in Amazonia. Since the end of the military regime, building on the 1988 constitution and revamped legal system, Brazil had put in place a relatively robust system of institutions that was responsible for developing and enforcing national environmental laws as well as meeting international obligations. These efforts, along with citizen activism and novel initiatives including supply-chain monitoring and using real-time clearing data to penalize environmental crimes, reduced deforestation by more than 70 percent in the decade from 2004 to 2014. There were real hopes for reaching desmatamento zerozero clearing in all of Brazil's biomes-by intensifying production on underused, already cleared land. This was the trend before the 2018 election brought Bolsonaro to power.

\section{GUTTING INSTITUTIONS}

At an ideological level, and at a further institutional and legal level, Bolsonaro's government set the stage for the Amazon apocalypse. The president has aggressively sought to undermine environmental and public health institutions and legislation, overriding reviews of the environmental impacts of projects and legalizing mining and infrastructure development on protected indigenous and traditional people's lands. His scorched-earth approach resembles the current US model under Trump. Indeed, Salles was invited to speak at the headquarters of the US Environmental Protection Agency at the behest of the Competitive Enterprise Institute, an outfit headed up by Myron Ebell, the éminence grise who served as the architect for the Trump administration's demolition of environmental safeguards.

Salles hardly needed tutoring in how to ruin an environmental agency. Shortly after taking the reins of his ministry, he began dismantling its own Brazilian Institute for the Environment (IBAMA).
He summarily dismissed 27 of the 29 regional agency heads, replacing them with military men, slashed the budget by more than 24 percent (on top of previous cuts), fired many of the field officers, and prohibited them from disabling deforestation equipment (such as tractors), which is a necessary step for stopping forest clearing. IBAMA was also prevented from prosecuting offenders who had been fined for illegal clearing. Operations on the ground were reduced by some 60 percent. ICMBio, the agency that is supposed to manage protected areas, handed out virtually no citations for illegal clearing in 2019, even though the vast extent of the damage was clearly visible in remotesensing images.

In 2019, a public letter from IBAMA employees in the Amazon described how they faced a rising pattern of terror, with arson attacks on their offices, their trucks destroyed, and the local police force, which used to protect them on their missions, now declining to help. The budget has been cut so deeply that there is barely any gas for the remaining trucks, and the staff is depleted by a high rate of attrition and widespread demoralization. They lamented that they could no longer act as protectors of forests, but instead had become impotent observers of the destruction of their life's work by the uncontrolled fires. This impotence was most apparent on August 10, dubbed the "day of burning," when ranchers, loggers, and other land grabbers set fire to the highly contested forests along the BR-163 highway, in open defiance of environmental law and IBAMA.

All of Brazil's previous environmental ministers have roundly denounced Salles's approach and policies, but to little avail. Gutting the government's environmental management institutions was not enough, however. The science that underpinned their programs is also on the line. In an expression of his disdain, Bolsonaro has defunded the Brazilian equivalent of the National Science Foundation, putting the nation's distinguished university system, scientists, and students in a precarious situation. The universities are facing cuts of more than 30 percent to their operating budgets.

Scientifically informed development policy for Amazonia had been the norm for the past several decades. The institutions that provided this expertise were supported and expanded even under the military regime from 1964 to 1985 . But under Bolsonaro, academic analysts have found themselves largely shut out of decisions. The few meetings they attended were crammed with obedient 
military men. Student training and research has languished, with fellowships cut off and classes canceled.

Meanwhile, the military advisers that replaced the climate negotiations staff had to be informed that Brazil was supposed to host the annual international meeting. The government canceled it, but the episode was emblematic of the cluelessness that characterized these inheritors of what had been one of the jewels in the crown of Brazilian diplomacy, as well as a mark of the country's respected scientific institutions and its stature on the world stage.

\section{FIRE STARTERS}

What has been triggering deforestation in Brazil? China's growth has driven international demand for commodities, heightened by the tariffs that Beijing placed on US soy and corn exports in retaliation for the Trump administration's tariffs on Chinese goods. This created more incentives for forest clearing, concurrently with the political rise of an agro-industrial bloc that seized the initiative with Bolsonaro as its point man. (Agricultural exports are Brazil's main source of foreign exchange.)

During Bolsonaro's 2018 presidential campaign, he advocated amnesty for deforesters and timber thieves, and pledged that he would recognize their claims to cleared land, rewarding illegal destruction. He planned to shut down the environment ministry, relax enforcement, reduce or eliminate environmental licensing for projects in the national interest, and withdraw from the Paris climate accord.

Bolsonaro also vowed to open up indigenous and traditional forest people's lands to mining, even though their land rights are inscribed in the constitution. He promised that Funai, the indigenous agency, would cease to be autonomous and would come under the aegis of the land ministry. "Not one inch of protected areas, indigenous lands, or kilombos [communities for slave descendants] will be demarcated on my watch," he boasted to an approving crowd of agro-industrialists. The candidate marshaled the usual racist tropes: Blacks were feckless, and indigenous people backward, so why should they hold so much land?

Bolsonaro has not fulfilled all of these promises since taking office. His brazenness gave pause even to some members of the Brazilian agro-industrial elite. Blairo Maggi, who owns the world's largest soy producer, fretted in an interview with the business newspaper Valor that withdrawing from the Paris Agreement could backfire and imperil market share in more environmentally concerned places like the EU, where deforestation-free commodity chains are increasingly important.

But Bolsonaro has succeeded in decriminalizing land grabbing, and that accounts for a great deal of what is going on now. The tried and true method is through clearing as a means of claiming land with fraud and force, throwing a few cattle on it to show that the land is "in use." There are enormous speculative gains to be made by selling land obtained in this way. The cattle system is famously unproductive (one animal per hectare) and serves mainly as a means of placeholding-in other words, creating an asset by privatizing public resources. It takes a few years before pasture land is ready to be worked for mechanized soy production, but it can be sold at enormous profit in the expanding frontier, especially in anticipation of the massive infrastructure plans for Amazonia that are part of the broader Initiative for the Integration of Regional Infrastructure in South America.

The government has reduced enforcement and even reviews of environmental and clearing licenses by more than 60 percent from previous years. Officials have stated that cattle lands created from protected areas no longer have conservation status and thus should be duly transferred to the clearer, essentially decriminalizing deforestation. Combined with encouraging presidential rhetoric, this kind of amnesty provides strong incentives for clearing lands.

Illegal deforestation has also occurred within reserves on landowners' property. The forest code indicates what proportion of property the owner must keep in natural vegetation, including riverbanks, slopes, and other types of forest areas. These protections are going unenforced as well.

Even if IBAMA knew about such violations, it would be powerless to act, as the August "day of burning" on protected areas near the BR-163 demonstrated. Here, Bolsonaro's left-wing predecessor as president, Luiz Inácio Lula da Silva, and his environment minister Marina da Silva had declared protected areas and reserves in order to buffer what had been basically a fire corridor for land speculators. In August, those who had formerly been responsible for protecting these 
forests looked on helplessly, like the rest of us. Deforestation is now infused with a new sense of impunity.

The clearing process is attended by a great deal of violence, because the forests are not empty. People live in them and use them. Human Rights Watch has noted the degree to which Amazonian deforestation has been outsourced to "forest mafias," a new innovation in the agro-industrial complex. These mafias operate in a manner similar to farm management services. Landowners can hire them them to carry out a "social cleansing" (limpieza social): they run local farmers and natives off the land, haul out the timber, and cut and burn what remains. Further out on the frontier, militias and gunmen drive people off their land, or kill them at a rate of about one per week, according to Global Witness. In just the first weeks of January 2020, five forest guardians were killed in Amazonas and Maranhão states (three were indigenous and two were peasants).

Apologists justify this violent process ideologically as a necessary, noble incarnation of the "march to the West," Brazil's version of manifest destiny. But the US notion of manifest destiny had within it the idea of a future. Bolsonaro's Brazil simply declares: The Amazon is ours-with or without a future.
There are alternatives, and they have worked: intensifying production on cleared land, promoting agroforestry systems like açaí and cacao, developing deforestation-free supply chains, supporting indigenous holdings and other forest guardians instead of assassinating their leaders, and recognizing that the fires next time will be worse. And they certainly will be worse, because the other Amazon countries-Bolivia, Peru, Ecuador, Colombia, and Venezuela-are in states of dysfunction, internal conflict, or collapse, and barely able to govern their capitals due to political unrest. Even if there are decent laws and policies, there is little political will or capacity to enforce them.

The default option today is clearing for claiming, as living forests are turned into ashes and assets everywhere. This is how the Amazon card is played to compensate for the failed development practices, political and economic corruption, and extreme inequality that characterize all these states. The policies and collaborations between governments and civil society that kept forests standing in many parts of Amazonia have come to an end, at least for now. What remains, as the great Brazilian writer Euclides da Cunha said about the Amazon in the midst of an earlier, rubber-driven commodity boom, are "men schooled in cataclysm, and builders of ruins." 